\title{
MOBILISASI DINI DAN PENURUNAN SKALA NYERI PADA PASIEN POST OPERASI TURP BENIGN PROSTATE HYPERPLASIA
}

\author{
I Wayan Sumberjaya ${ }^{1}$, I Made Mertha ${ }^{2}$ \\ ${ }^{1}$ Program Studi S1 Keperawatan STIKES Bina Usada Bali \\ ${ }^{2}$ Politeknik Kesehatan Kemenkes Denpasar
}

Denpasar,Bali,Indonesia

Wayansumberjaya2006@gmail.com¹,mdmertha69@gmail.com²

Abstract: Pain is an unpleasant symptom experienced by patients who undergoing post surgery of TURP BPH. This study aimed to determine the effect of early mobilization on reducing pain scale in post surgery patients with TURP BPH. The design of this study was one group pre-post test design with a pre-experimental design, with a total sample was 12 respondents using purposive sampling technique. The instrument used in this study was guide sheet in the form of Standard Operating Procedures (SOP) and a pain gauge in the form of Numeric Rating Scale (NRS). Pain scale before early mobilization, 2 respondents (16.7\%) were with pain scale 6 and 3 respondents (25\%) were with pain scale 3. After early mobilization, 1 respondent (8.3\%) was with pain scale 5 and 3 respondents (25\%) were with pain scale 2 . Wilcoxon test results obtained $p$-value $=0.0001<0.05$, it means that the provision of early mobilization had a significant effect on pain scale reduction in post surgery patients with TURP Benign Prostate Hyperplasia (BPH) in Bima Ward Sanjiwani Regional Hospital Gianyar. The results of the study concluded that there was effect on pain scale reduction in post surgery patients with TURP BPH.

Keywords: Early Mobilization, Pain, pot operation, benign prostat hyperplasia

Abstrak: Mobilisasi dini dan penurunan skala nyeri pada pasienpost operasi turp benign prostate hyperplasia.Penelitian ini bertujuan untuk mengetahui pengaruh mobilisasi dini terhadap penurunan skala nyeri pada pasien post operasi TURP BPH. Desain penelitian ini adalah one group pra-post test design dengan rancangan pra experimental, jumlah sampel sebanyak 12 responden menggunakan teknik purposive sampling. Instrument yang digunakan dalam penelitian ini adalah lembar panduan berupa Standar Operasional Prosedur (SOP) dan alat ukur nyeri berupa Numeric Rating Scale (NRS). Skala nyeri sebelum mobilisasi dini, 2 responden $(16,7 \%)$ dengan skala nyeri 6 dan 3 responden $(25 \%)$ dengan skala nyeri 3 . Setelah mobilisasi dini, 1 responden $(8,3 \%)$ dengan skala nyeri 5 dan 3 responden (25\%) dengan skala nyeri 2 . Hasil uji wilcoxon didapatkan $\mathrm{p}$-value $=0,0001<0,05$, ini berarti bahwa pemberian tindakan mobilisasi dini berpengaruh signifikan terhadap penurunan skala nyeri pada pasien post operasi TURP BPH di ruang Bima RSUD Sanjiwani Gianyar. Hasil penelitian disimpulkan ada pengaruh mobilisasi dini terhadap penurunan skala nyeri pada pasien post operasi TURP BPH.

Kata Kunci: Mobilisasi Dini, Nyeri, post op, benign prostat hyperplasia 


\section{PENDAHULUAN}

Benign Prostat Hiperplasi adalah kelenjar prostat yang mengalami pembesaran, yang dapat menyumbat uretra pars prostatika dan menyebabkan terhambatnya aliran urine keluar dari bulibuli. ${ }^{1)}$ Berdasarkan data World Health Organization (WHO) tahun 2018 memperkirakan sekitar 59 pria dari 100.000 penduduk menderita BPH atau sekitar 70 juta diseluruh dunia. Di Indonesia, BPH menjadi urutan kedua setelah penyakit batu saluran kemih, dan secara umum, diperkirakan hampir 50\% pria di Indonesia yang berusia di atas 50 tahun ditemukan menderita $\mathrm{BPH}$ atau diperkirakan sebanyak 2,5 juta orang. Angka kejadian BPH di Provinsi Bali berdasarkan data profil kesehatan Provinsi Bali tahun 2018 sebanyak 4.122 orang dimana penderita BPH tertinggi ada di Kabupaten Gianyar yaitu sebesar 794 kasus. Angka kejadian BPH di RSUD Sanjiwani Gianyar Tahun 2018 sebanyak 605 kasus sedangkan pada periode Januari sampai April 2019 mencapai 49 kasus.

Penatalaksanaan jangka panjang pada pasien dengan BPH adalah dengan melakukan pembedahan. Salah satu tindakan yang paling banyak dilakukan pada pasien dengan BPH adalah tindakan pembedahan Transurethral Resection Of the Prostate (TURP) yang prosedur pembedahan dengan memasukkan resektoskopi melalui uretra untuk mengeksisi dan mereseksi kelenjar prostat yang mengalami obstruksi. Prosedur tersebut menimbulkan luka bedah yang berakibat menimbulkan nyeri pada luka post operasi. ${ }^{1)}$ Prevalensi nyeri pasca operasi dalam sampel 1490 klien rawat inap bedah, didapatkan hasil nyeri sedang atau berat dilaporkan oleh $41 \%$ klien pada hari $0,30 \%$ pada hari 1 dan $19 \%, 16 \%$ dan $14 \%$ pada hari 2,3 , dan 4 . Prevalensi nyeri sedang atau berat pada kelompok pembedahan perut adalah tinggi pada harihari pasca operasi $0-1$ (30-55\%). Salah satu intervensi keperawatan yang sering dilakukan pada pasien pasca operasi adalah dengan mobilisasi dini.

Mobilisasi dini mempunyai peranan penting dalam mengurangi rasa nyeri dengan cara menghilangkan konsentrasi pasien pada lokasi nyeri atau daerah operasi, mengurangi aktivasi mediator kimiawi pada proses peradangan yang meningkatkan respon nyeri serta meminimalkan transmisi saraf nyeri menuju saraf pusat. Melalui mekanisme tersebut, mobilisasi dini efektif dalam menurunkan intensitas nyeri pasca operasi. ${ }^{2)}$

Hasil studi pendahuluan yang dilakukan pada bulan April 2019 di Ruang Bima RSUD Sanjiwani Gianyar diperoleh data dari wawancara dengan pasien, diperoleh data bahwa 4 dari 6 pasien post operasi TURP masih membatasi aktifitasnya karena masih merasa nyeri hebat meskipun sudah memperoleh terapi farmakologi. Selain itu intervensi untuk melakukan mobilisasi dini juga berpengaruh terhadap penurunan nyeri pasien. Apalagi RSUD Sanjiwani Gianyar telah menerapkan Clinical Pathway (CP) untuk penyakit $\mathrm{BPH}$, sehingga pasien bisa diberikan edukasi untuk melakukan mobilisasi dini. Penelitian ini bertujuan untuk mengetahui pengaruh mobilisasi dini terhadap penurunan skala nyeri pada pasien post operasi TURP BPH di Ruang Bima RSUD Sanjiwani Gianyar.

Benign Prostate Hyperplasia (BPH) atau pembesaran prostat jinak merupakan suatu keadaan terjadinya proliferasi sel stroma prostat yang akan menyebabkan pembesaran dari kelenjar prostat. ${ }^{3)}$ 
Klasifikasi BPH. Penyebab terjadinya $\mathrm{BPH}$ hingga sekarang masih belum diketahui secara pasti, namun beberapa hipotesis menyebutkan bahwa $\mathrm{BPH}$ erat kaitanya dengan peningkatan kadar dehidrotestosteron (DHT) dan proses menua.

Manifestasi klinis BPH mencakup keluhan pada saluran kemih bagian bawah, gejala pada saluran kemih bagian atas, dan gejala di luar saluran kemih. ${ }^{(1)}$ Keluhan pada saluran kemih bagian bawah meliputi gejala obstruksi seperti retensi urin (urin tertahan dikandung kemih sehingga urin tidak bisa keluar), hesitansi (sulit memulai miksi), pancaran miksi lemah, Intermiten (kencing terputus-putus), dan miksi tidak puas (menetes setelah miksi). Gejala iritasi meliputi nokturia, urgensi (perasaan ingin miksi yang sangat mendesak) dan disuria (nyeri pada saat miksi). Keluhan pada saluran kemih bagian atas akibat hiperplasi prostat pada saluran kemih bagian atas berupa adanya gejala obstruksi, seperti nyeri pinggang, benjolan dipinggang (merupakan tanda dari hidronefrosis), atau demam yang merupakan tanda infeksi atau urosepsis. Keluhan diluar saluran kemih biasanya pasien datang diawali dengan keluhan penyakit hernia inguinalis atau hemoroid. Timbulnya penyakit ini dikarenakan sering mengejan pada saat miksi sehingga mengakibatkan tekanan intra abdominal. Adapun gejala dan tanda lain yang tampak pada pasien BPH, pada pemeriksaan prostat didapati membesar, kemerahan, dan tidak nyeri tekan, keletihan, anoreksia, mual dan muntah, rasa tidak nyaman pada epigastrik, dan gagal ginjal dapat terjadi dengan retensi kronis dan volume residual yang besar. ${ }^{1)}$

Penatalaksanaan BPH berupa tindakan operasi yaitu Transurethral Resection of the Prostate (TURP), yang merupkan prosedur pembedahan yang dilakukan melalui endoskopi. TURP dilaksanakan bila pembesaran terjadi pada lobus tengah yang langsung melingkari uretra. Masalah keperawatan yang umum dialami oleh pasien post operasi TURP adalah nyeri.

Nyeri menurut Asosiasi Internasional untuk penelitian nyeri (internatonal Association for the Study of Pain, IASP) didefinisikan sebagai suatu sensori subjektif dan pengalaman emosional yang tidak menyenangkan berkaitan dengan kerusakan jaringan yang aktual atau potensial atau yang dirasakan dalam kejadian di mana terjadi kerusakan. ${ }^{(4)}$ Nyeri dapat disebabkan karena adanya kerusakan jaringan dalam tubuh sebagai akibat dari adanya cedera, kecelakaan, maupun tindakan medis seperti operasi. ${ }^{(5)}$ Berdasarkan derajat nyeri dikelompokkan menjadi nyeri ringan, nyeri sedang, dan nyeri berat. Faktor yang mempengaruhi nyeri antara lain usia, kebudayaan, pengalaman sebelumnya gaya koping, dan dukungan keluarga dan sosial.

Pengukuran skala nyeri dapat dibagi atas pasien yang memiliki kemampuan verbal dan dapat melaporkan sendiri rasa sakitnya (self reported) dan pasien dengan ketidakmampuan verbal baik karena terganggu kognitifnya, dalam keadaan tersedasi, ataupun berada dalam mesin ventilator. Pengukuran skala nyeri tersebut dapat berupa Numerical Rating Scale (NRS), Visual Descriptif Scale (VDS), dan Visual Analogue Scale (VAS). Numerical Rating Scale (NRS) yang umum digunakan dengan menggunakan skala numerik dari 0 hingga 10 , dengan angka nol (0) merupakan keadaan tanpa atau bebas nyeri, sedangkan sepuluh (10), suatu nyeri yang sangat hebat. ${ }^{6}$ )

Tindakan keperawatan yang dapat dilakukan pada pasien BPH post operasi TURP yang mengalami nyeri adalah 
mobilisasi dini. Mobilisasi dini merupakan aktivitas yang dilakukan pasien post pembedahan dimulai dari latihan ringan di atas tempat tidur (latihan pernafasan, latihan batuk efektif dan menggerakkan tungkai) sampai dengan pasien bisa turun dari tempat tidur, berjalan ke kamar mandi dan berjalan keluar kamar. ${ }^{7}$ Mobilisasi pada pasien dapat dilakukan secara penuh maupun sebagian. Mobilisasi penuh, merupakan kemampuan seseorang untuk bergerak secara penuh dan bebas sehingga dapat melakukan interaksi sosial dan menjalankan peran sehari-hari. Mobilitas penuh ini merupakan fungsi saraf motorik volunter dan sensorik untuk dapat mengontrol seluruh area tubuh seseorang. ${ }^{8)}$ Mobilisasi sebagian, merupakan kemampuan seseorang untuk bergerak dengan batasan jelas dan tidak mampu bergerak secara bebas karena dipengaruhi oleh gangguan saraf motorik dan sensorik pada area tubuhnya.

Tujuan mobilisasi dini adalah mempertahankan fungsi tubuh, memperlancar peredaran darah, membantu pernapasan menjadi lebih baik, mempertahankan tonus otot, memperlancar eliminasi buang air besar (BAB) dan buang air kecil (BAK), mengembalikan aktivitas tertentu sehingga pasien dapat kembali normal memenuhi kebutuhan gerak harian, dan memberi kesempatan perawat dan pasien untuk berinteraksi dan berkomunikasi. ${ }^{9}$ ) Tujuan mobilisasi dini adalah menurunkan kejadian komplikasi thrombosis vena, emboli paru, pneumonia dan retensi urin serta meningkatkan kepuasan pasien dan mengurangi long of stay (LOS) lama hari rawat pasien.

Faktor Yang Mempengaruhi Mobilisasi gaya hidup, proses penyakit dan injury, kebudayaan, tingkat energy, dan usia dan status perkembangan. ${ }^{10)}$
Manfaat mobilisasi pada post operasi adalah: 1).Peningkatan kecepatan dan kedalaman pernafasan sehingga mencegah atelektasis dan pneumonia hipostatis, peningkatan kesadaran mental dampak dari peningkatan oksigen ke otak, 2). Peningkatan sirkulasi, nutrisi untuk penyembuhan mudah didapat pada daerah luka, dapat mencegah thrombophlebitis, peningkatan kelancaran fungsi ginjal, pengurangan rasa nyeri, 3). Peningkatan metabolisme, mencegah berkurangnya tonus otot dan mengembalikan keseimbangan nitrogen, 4). Peningkatan berkemih sehingga mencegah retensi urin, dam 5). Peningkatan peristaltik sehingga memudahkan terjadinya flatus, mencegah distensi abdominal dan nyeri akibat gas, mencegah konstipasi, mencegah illeus paralitik.

\section{METODE}

Penelitian ini merupakan penelitian eksperimen dengan menggunakan rancangan pre experiment. Penelitian preeksperimen atau pre-experimental designs merupakan rancangan penelitian yang belum dikategorikan sebagai eskperimen sungguhan. Dalam rancangan dalam penelitian ini menggunakan pre dan post test one group design. Pengukuran akhir (post test) dilakukan pada semua kelompok untuk menentukan efek perlakuan pada responden.

\section{HASIL DAN PEMBAHASAN}

Tabel 1

Karakteristik Responden Berdasarkan

Umur

\begin{tabular}{|c|c|c|c|c|c|}
\hline $\begin{array}{l}\text { Vari } \\
\text { able }\end{array}$ & $\mathrm{N}$ & $\begin{array}{c}\mathrm{Mi} \\
\mathrm{n}- \\
\mathrm{ma} \\
\mathrm{x}\end{array}$ & $\begin{array}{c}\text { Rat } \\
\text { a- } \\
\text { rata }\end{array}$ & $\begin{array}{c}\text { Standa } \\
\text { r } \\
\text { Devias } \\
\text { i }\end{array}$ & $\begin{array}{c}\text { Media } \\
\mathrm{n}\end{array}$ \\
\hline Umu & 1 & 50- & 66,7 & 1.084 & 4.42 \\
\hline
\end{tabular}


$\begin{array}{lll}\text { r } & 2 & 80\end{array}$

Berdasarkan table 1. terlihat bahwa karakteristik responden berdasarkan umur minimal 50 tahun, maksimal 80 tahun dengan rata-rata umur 67 tahun.

Tabel 2

Karakteristik Responden Berdasarkan Pendidikan

\begin{tabular}{ccc} 
Pendididkan & $\begin{array}{c}\text { Frekuensi } \\
(\mathrm{n})\end{array}$ & $\begin{array}{c}\text { Persentase } \\
(\%)\end{array}$ \\
\hline SD & 1 & 8 \\
\hline SLTP & 1 & 8 \\
\hline SLTA & 5 & 42 \\
\hline Akademi/PT & 5 & 42 \\
\hline Jumlah & 12 & 100 \\
\hline
\end{tabular}

Berdasarkan tabel 2 terlihat bahwa karakteristik responden berdasarkan pendidikan sebagian besar responden berpendidikan SLTA responden (42\%) dan Akademi / PT 5 responden (42\%).

\section{Tabel 3}

Karakteristik Responden Berdasarkan Pekerjaan

\begin{tabular}{cc}
\hline \multirow{2}{*}{ Pekerjaan } & \\
\cline { 2 - 2 } & Frekuensi (n) \\
\hline Swasta/wiraswasta & 7 \\
\hline Tidak bekerja & 3 \\
\hline PNS/TNI/POLRI & 2 \\
\hline Jumlah & 12 \\
\hline
\end{tabular}

Berdasarkan table 3, terlihat bahwa karakteristik responden berdasarkan pekerjaan didominasi oleh responden dengan status pekerjaan swasta / wiraswasta sebanyak 7 responden (58\%).

Berdasarkan hasil penelitian menurut karakteristik diatas dapat dinyatakan permasalahan kesehatan pada laki-laki, seiring dengan bertambahnya umur, maka akan terjadi perubahan keseimbangan testosterone dan estrogen karena produksi testoteron menurun dan akan terjadi konversi testosterone menjadi esterogen pada jaringan adiposa di perifer sehingga memicu pertumbuhan atau pembesaran prostat yang sering disebut dengan Benign Prostate Hyperplasia $(\mathrm{BPH}){ }^{11)}$

Hasil penelitian ini relevan dengan penelitian tentang pengaruh mobilisasi dini terhadap nyeri post operasi TURP pada pasien BPH di RSU PKU Muhammadiyah Bantul diketahui bahwa usia responden kelompok eksperimen sebagian besar masuk dalam rentang usia $>65$ tahun sebanyak 11 orang $(73,3 \%)$. Usia responden pada kelompok kontrol sebagian besar masuk dalam rentang usia $>65$ tahun sebanyak 11 orang $(73,3 \%)$. Pekerjaan responden kelompok intervensi sebagian besar adalah buruh/petani sebanyak 11 orang (73,3\%). Pekerjaan responden kelompok kontrol sebagian besar adalah buruh/petani sebanyak 8 orang $(53,3 \%)$. Status perkawinan responden kelompok intervensi sebagian besar adalah menikah sebanyak 14 orang $(93,3 \%)$. Status perkawinan responden kelompok kontrol seluruhnya adalah

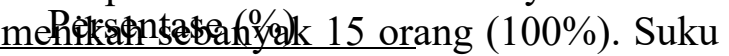
bangsa pesponden kelompok intervensi sebagian 2besar adalah Jawa sebanyak 14 orang (9B73\%). Suku bangsa kelompok kontrol sleQ0ruhnya suku Jawa sebanyak 15 orang (100\%). Tingkat pendidikan responden kelompok intervensi sebagian besar adalah SD sebanyak 6 orang (40\%). Tingkat pendidikan responden kelompok kontrol sebagian besar adalah SD sebanyak 9 orang $(60 \%) .{ }^{12)}$

Benign Prostat Hiperplasia (BPH) dijumpai pada lebih dari pria berusia diatas 50 tahun. BPH dapat menyebabkan penekanan pada uretra ditempat uretra menembus prostat sehingga berkemih menjadi sulit, mengurangi kekuatan aliran urine, atau menyebabkan urine menetes. 


\section{Tabel 4}

Skala Nyeri Responden Sebelum dan Setelah Diberikan Tindakan Mobilisasi Dini

\begin{tabular}{ccccc}
\hline Variabel & $\begin{array}{c}\text { Mean } \\
\pm \text { SD }\end{array}$ & Median & Min & Max \\
\hline Sebelum & 4,42 & 4,50 & 3 & 6 \\
& \pm & & & \\
& 1,084 & & & \\
\hline Setelah & $3,25 \pm$ & 3,0 & 2 & 5 \\
& 0,965 & & & \\
\hline
\end{tabular}

Berdasarkan tabel 4 atas, diperoleh bahwa skala nyeri responden post operasi sebelum diberikan tindakan mobilisasi dini berkisar antara 3-6 dengan rata-rata adalah 4,42 . Dimana minimal skala nyerinya 3 yang berarti skala nyeri ringan dari skala nyeri 1-3, dan maksimal skala nyerinya 6 yang berarti nyeri sedang dari skala nyeri 4-6.

Skala nyeri responden yang mengalami post operasi sesudah diberikan tindakan mobilisasi dini berkisar antara 25 dengan rata-rata 3,25. Dimana minimal skala nyerinya 2 yang berarti skala nyeri ringan dari skala nyeri 1-3, dan maksimal skala nyerinya 5 yang berarti nyeri sedang dari skala nyeri 4-6.

Berdasarkan skala nyeri sebelum dan setelah mobilisasi diatas dapat dinyatakan bahwa secara deskriptif menunjukkan bahwa responden yang diberikan tindakan mobilisasi dini pada pasien post operasi terjadi penurunan nyeri.

\section{Tabel 5}

Analisis Pengaruh Diberikan Tindakan

Mobilisasi Dini Terhadap Penurunan

Skala Nyeri Pasien Post Operasi Dengan

$$
\text { Uji Wilcoxon }
$$

\begin{tabular}{cccc}
\hline $\begin{array}{c}\text { Hasil uji } \\
\text { wilcoxon }\end{array}$ & N & $\begin{array}{c}\text { Mean } \pm \\
\text { SD }\end{array}$ & $\begin{array}{c}\text { p- } \\
\text { value }\end{array}$ \\
\hline Skala nyeri pre & 12 & $4,42 \pm$ & 0,0001 \\
\end{tabular}

\begin{tabular}{l}
\hline \multicolumn{2}{c}{1,084} \\
Skala nyeri \\
post \\
Berdasarkan hasil uji statistik \\
$0,965 \pm$ \\
dengan menggunakan uji Wilcoxon, \\
diperoleh nilai signifikansi P-value = \\
0,0001 dengan taraf signifikansi $95 \%(\alpha$ \\
$=0,05)$. Hal ini berarti H1 diterima \\
sehingga dapat disimpulkan terdapat \\
pengaruh mobilisasi dini terhadap \\
penurunan skala nyeri pada pasien post \\
operasi TURP BPH di Ruang Bima RSUD \\
Sanjiwani Gianyar. \\
Hal ini relevan dengan penelitian
\end{tabular}
tentang pengaruh mobilisasi dini terhadap nyeri post operasi TURP pada pasien BPH di RSU PKU Muhammadiyah Bantul menunjukkan intensitas nyeri post operasi TURP pada pasien BPH sebelum dilakukan mobilisasi dini pada kelompok intervensi sebagian besar adalah pada skala 3 sebanyak 6 orang (40\%). Intensitas nyeri post operasi TURP pada kelompok kontrol sebagian besar pada skala 5 sebanyak 5 orang $(33,3 \%) .{ }^{12)}$ Menurut peneliti pasien post operasi akan mengalami nyeri sedang sampai berat karena kerusakan jaringan akibat tindakan operasi tersebut seiring dengan berkurangnya efek obat anastesi.

Mobilisasi dini mempunyai peranan penting dalam mengurangi rasa nyeri dengan cara menghilangkan konsentrasi pasien pada lokasi nyeri atau daerah operasi, mengurangi aktivasi mediator kimiawi pada proses peradangan yang meningkatkan respon nyeri serta meminimalkan transmisi saraf nyeri menuju saraf pusat. Melalui mekanisme tersebut, mobilisasi dini efektif dalam menurunkan intensitas nyeri pasca operasi. ${ }^{2)}$

Nyeri yang dirasakan sebelum diberi mobilisasi dini rata-rata dirasakan 
ketika responden menggerakkan bagian tubuh yang telah dioperasi, namun nyeri yang dirasakan tidak sampai mengganggu aktivitas responden. Setelah dilakukan teknik mobilisasi dini, sebagian responden mengatakan bahwa nyeri yang dirasakan berkurang.

Sesuai dengan intervensi yang diberikan, mobilisasi dini merupakan salah satu penanganan post operasi non farmakologi yang efisien dan ekonomis, serta efek samping yang ditimbulkan juga relatif aman. Penurunan nyeri setelah diberikan tindakan mobilisasi dini diakibatkan oleh pergerakan otot yang menyebabkan penutupan gerbang nyeri dan nosiseptor nyeri. Mobilisasi dini merupakan pemanfaatan untuk mengobati nyeri dan mengurangi gejala peradangan lainnya.

Efek terapeutik dari mobilisasi dini meliputi; menurunkan diameter konduksi saraf sehingga menurunkan persepsi nyeri, mengurangi respon peradangan pada jaringan, mengurangi aliran darah dan mengurangi edema. Selain itu, sesuai dengan teori "gate kontrol" menjelaskan bagaimana impuls rasa nyeri termodulasi yaitu aliran impuls rasa nyeri aferen dapat dihambat atau diteruskan dalam substansi gelatinosa di korda spinalis atau nukleus sehingga impuls yang menimbulkan berbagai sensasi dapat ditransmisikan bersama, dimodifikasikan dan dihambat. ${ }^{13)}$ Dalam hal ini, dianggap bahwa pintu gerbang juga dipengaruhi oleh serabut desenden pada sistem aktivitas retikuler dan ini merupakan mekanisme dimana masukan sensorik alternatif dapat menurunkan atau menghilangkan persepsi rasa sakit.

Pendapat lain menyatakan bahwa efek mobilisasi dini adalah meningkatkan vasokontriksi mengakibatkan penurunan aliran darah ke daerah terinflamasi sehingga mengurangi peradangan dan edema. ${ }^{6)}$ Hal tersebut berarti, secara langsung tindakan mobilisasi dini mengurangi mediator-mediator inflamasi yang mengaktivasi dan mensensitisasi ujung-ujung saraf nyeri sehingga nyeri yang dipersepsikan berkurang. Jadi, berdasarkan penjelasan tersebut terbukti hasil analisis yang dilakukan dengan uji Wilcoxon bahwa tindakan mobilisasi dini yang diberikan dapat menurunkan skala nyeri pasien post operasi $(\mathrm{P}$-value $=$ $0,0001<0,05)$.

Penelitian ini juga diperkuat dalam penelitian tentang Pengaruh Mobilisasi Dini Terhadap Keberhasilan Penyembuhan Luka pada Pasien Pasca Operasi Di RS Pkumuhammadiyah Yogyakarta Tahun 2013, diperoleh hasil dari responden terbukti bahwa teknik mobilisasi dini dapat menurunkan skala nyeri pada pasien kontusio dengan nilai $\mathrm{P}$ $\left.=0,000 \quad(\mathrm{p}<0.05) .{ }^{14}\right)$ Penelitian lainnya membuktikan terhadap perubahan tingkat nyeri klien post operasi apendektomy di Rumah Sakit Baladhika Husada Kabupaten Jember. $p=0,000$ yang menunjukkan bahwa ada perbedaan yang signifikan antara skala nyeri sebelum dan setelah dilakukan mobilisasi dini. ${ }^{15)}$

Berdasarkan hasil penelitian, teori serta penelitian-penelitian terdahulu peneliti berasumsi teknik mobilisasi dini merupakan intervensi keperawatan secara mandiri untuk menurunkan skala nyeri yang tidak membutuhkan peralatan khusus, mudah dilakukan kapan saja dan dimana saja, tidak memerlukan keahlian khusus dan terbukti efektif dalam menurunkan skala nyeri. Teknik mobilisasi dini bisa dijadikan alternatif dalam mengurangi intensitas nyeri pasca operasi selain obat analgetik. 


\section{SIMPULAN}

Pemberian tindakan mobilisasi dini berpengaruh terhadap penurunan skala nyeri pasien post operasi TURP BPH di Ruang Bima RSUD Sanjiwani Gianyar (Pvalue $=0,0001<0,05)$.

\section{UCAPAN TERIMAKASIH}

Ucapan terima kasih di sampaikan kepada Direktur RSU Sanjiwani Gianyar yang telah memberikan dukungan dalam melakukan penelitian ini.Kepada Kepala Ruangan Bima dan Perawat lainnya yang telah memberikan bantuan dan dukungan moral saat pelaksanaan penelitian.

\section{ETIKA PENELITIAN}

Etika penelitian diperoleh di institusi pendidikan STIKES Bina Usada Bali

\section{SUMBER DANA}

Penelitian ini merupakan penelitian swadana dari peneliti.

\section{DAFTAR RUJUKAN}

1. Purnomo BB. Dasar-Dasar Urologi. Jakarta: CV Sagung Seto; 2011.

2. Nugroho T. Buku Askep Maternitas, Anak, Bedah, Penyakit Dalam. Bantul: Nuha Medika; 2011.

3. Kapoor. Benign Prostatic Hyperplasia (BPH) Management in The Primary Care Setting. Canada: J. Urol; 2012.

4. Judha M, Sudarti, Fauziah A. Teori Pengukuran Nyeri. Yogyakarta: Nuha Medika; 2012. 36 p.

5. Ratnasari N, Ratna, M J. Pengaruh Pemberian Guided Imagery Terhadap Nyeri Pada Pasien Post Operasi Fraktur di RSUD Panembahan Senopati Bantul. Respati. 2013;
6. Potter \& Perry. Fundamental on Nursing. 3th ed. Jakarta: Salemba Medika; 2010.

7. Ibrahim M. Pengetahuan Pasien Tentang Mobilisasi Post Operasi Appendisitis di Ruang Bedah RSUD Prof. Dr Aloei Saboe Kota Gorontalo. 2839-2829-1-PB. 2013;

8. Hidayat AA. Pengantar Konsep Dasar Keperawatan. Jakarta: Salemba Medika; 2009. 119 p.

9. Garrison S. Dasar-Dasar Terapi dan Latihan Fisik. Jakarta: Hypocrates; 2011.

10. Kozier B, Erb B, Snyder. Fundamental of Nursing Concenpts Process and Practice. 6th ed. New Jersey: Person/Prentice Hall; 2010.

11. Sjamsuhidajat \& De Jong. Buku Ajar Ilmu Bedah. Jakarta: EGC; 2010.

12. Wulandari A. Pengaruh Mobilisasi Dini Terhadap Nyeri Post Operasi TURP Pada Pasien BPH di RSU PKU Muhammadiyah Bantul. 2018;

13. Smeltzer \& Bare. Buku Ajar Keperawatan Medikal Bedah. 8th ed. Jakarta: EGC; 2013.

14. Anggraini M. Pengaruh Mobilisasi Dini Terhadap Keberhasilan Penyembuhan Luka Pada Pasien Pasca Operasi di RS PKU Muhammadiyah. J Kesehat Komunitas. 2009;1-18.

15. Pristahayuningtyas RC. Pengaruh Mobilitas Dini Terhadap Perubahan Tingkat Nyeri Klien Post Operasi Apendiktomi di Ruang Bedah Mawar Rumah Sakit Baladhika Husada Kabupaten Jember. J Keperawatan Univ Jember. 2014;1106. 